\title{
Determination of evapotranspiration and crop coefficient for cauliflower at Paraná northwest region
}

André Felipe Barion Alves Andrean, Roberto Rezende, Vinícius Villa e Vila, Lucas Henrique Maldonado da Silva, Gustavo Soares Wenneck

Universidade Estadual de Maringá - UEM, PR. E-mail: andre andrian@hotmail.com

\begin{abstract}
Evapotranspiration and the estimation of crop coefficient $(\mathrm{Kc})$ are essential information for irrigation management, contributing to increase the water use efficiency and optimizing resources, mainly using local data. This study aimed to determine the water consumption and the crop coefficient of cauliflower (Barcelona hybrid) in the northwestern region of Paraná. The experiment was conducted in a greenhouse at the Technical Irrigation Center belonging to the State University of Maringá, in Maringá - PR. The crop evapotranspiration was determined using constant water table lysimeters, and the reference evapotranspiration was estimated by the Penman-Monteith method (FAO), using climatological data collected in an automatic meteorological station. The cultivation was carried out from April to July. The total water consumption by the cauliflower was $215.11 \mathrm{~mm}$, a higher value than that available in the FAO recommendations. The crop coefficient $(\mathrm{Kc})$ recommended values for local conditions are 0.74 for the initial stage, 1.86 for the intermediate stage, and 1.50 for the final stage.
\end{abstract}

Keywords: Brassica oleracea var. botrytis; irrigation management; lysimeter; water consumption.

\section{Determinação da evapotranspiração e coeficiente da cultura da couve-flor na região noroeste do Paraná}

\section{Resumo}

A evapotranspiração e a estimativa dos coeficientes da cultura $(\mathrm{Kc})$ são informações fundamentais para o manejo da irrigação, contribuindo para o aumento da eficiência no uso da água e otimização dos recursos, principalmente a utilizar dados locais. $O$ trabalho teve como objetivo determinar o consumo hídrico e o coeficiente da cultura da couve-flor (híbrido Barcelona) na região noroeste do Paraná. O experimento foi conduzido em casa de vegetação no Centro Técnico de Irrigação pertencente à Universidade Estadual de Maringá, em Maringá - PR. A evapotranspiração da cultura foi determinada utilizando lisímetros de lençol freático constante, e a evapotranspiração de referência foi estimada pelo método de Penman-Monteith (FAO), a partir de informações climatológicas coletadas em estação meteorológica automática. O cultivo foi realizado no período de abril a julho. O consumo total de água pela cultura da couve-flor foi de $215,11 \mathrm{~mm}$, sendo um valor maior do que o disponível nas recomendações da FAO. Os valores recomendados de coeficiente da cultura (Kc) para as condições de cultivo são de 0,74 para o estádio inicial, 1,86 para o estádio intermediário e 1,50 para o estádio final.

Palavras-chave: Brassica oleracea var. botrytis; manejo da irrigação; lisímetro; consumo hídrico.

\section{Introduction}

Cauliflower (Brassica oleracea var. botrytis) is a species belonging to the Brassicaceae family. Environmental conditions, mainly temperature, are limiting factors for the production, and the South and
Southeast are the major producers regions in Brazil. However, management practices enable cultivation in the mid-season and summer with satisfactory profitability (FERREIRA et al., 2019; OLIVEIRA et al., 2018; PEREIRA et al., 2018). 
Because of the superficial root system, cauliflower is intolerant to long periods of water deficit, which can compromise vegetative growth, causing a reduction of potential yield (MAY et al., 2007). In hydric stress conditions, plants can show changes in morphological and physiological components, causing a direct impact on crop yield (FERREIRA et al., 2019). Irrigation based on different technical criteria allows supply crop demands, decreasing environmental impact, and optimizing resource utilization (SANTOS et al., 2018).

According to Coutinho et al. (2020), improper use of water by agricultural production shows a high impact on the productive sector and society. The determination of adequate amounts for irrigation is one relevant factor. One of the technical criteria to be used in an irrigated crop is the plant evapotranspiration supplied by the irrigation, conditioning crop to reach the maximum potential productivity (LOZANO et al., 2017).

Different equations are utilized to estimate the reference evapotranspiration (ETo) based on climate data, being the PenmanMonteith method recommended by FAO (Food and Agriculture Organization). Crop evapotranspiration can be indirectly determined using reference evapotranspiration values and crop coefficient $(\mathrm{Kc})$. Thus, the Kc presents great relevance to estimating crop water necessities (MANGAROTTI et al., 2019).

The success of water utilization by irrigation depends, among other requirements, on accurate knowledge of crop demand. Thus, the use of adequate coefficients is necessary, especially $\mathrm{Kc}$ that is determined in function of crop evapotranspiration (ETc) and ETo.

The crop can be affected by several factors, stomatal resistance caused by adverse atmospheric conditions, plant morphology, soil fertility, the occurrence of pests and diseases, irrigation interval, water availability, soil characteristics, and sowing density (TAIZ; ZEIGER, 2017; SANTOS et al., 2018). So this factors can affect the crop coefficient.

The $\mathrm{Kc}$ determination must be done in function of crop phenological stages, varying according to the location and climate where it is being assessed (BARBOSA et al., 2015). Research about regional $\mathrm{Kc}$ determination is essential because it provides greater reliability in local evapotranspiration rates (LOZANO et al., 2017; MARGAROTTI et al., 2019; SANTOS et al., 2020).
The present study aims to determine the hydric consumption and Kc on different phenological stages of cauliflower cultivated in a greenhouse at Paraná northwest region and compare with FAO irrigation and drainage paper 56.

\section{Material and methods}

The study was conducted at Irrigation Technical Center, from Maringá State University, situated at $23^{\circ} 25^{\prime} \mathrm{S}, 51^{\circ} 57^{\prime} \mathrm{W}$, and altitude of 542 $\mathrm{m}$ (Maringá, state of Paraná). Climate is classified as Cfa (humid subtropical climate) according to Köppen classification, with annual precipitation of $1500 \mathrm{~mm}$, average temperature between $28^{\circ} \mathrm{C}$ and $29^{\circ} \mathrm{C}$ (MONTANHER; MINAKI, 2020).

The experiment was conducted in a greenhouse, arched roof, covered with lowdensity polyethylene (thickness of $150 \mu \mathrm{m}$ ) and side protected by a nylon screen. Greenhouse dimension is $25 \mathrm{~m}$ long, $7 \mathrm{~m}$ wide, and $3.5 \mathrm{~m}$ headroom.

The soil of the experimental area is classified as NITOSSOLO VERMELHO Distroférrico corresponding to an Ultisol in the soil taxonomy classification (SANTOS et al., 2018). Presenting as chemical characteristics: base saturation $(\mathrm{V} \%)=$ 81.08; cation exchange capacity $(\mathrm{CEC})=12.95$ $\mathrm{cmol}_{\mathrm{c}} \mathrm{dm}^{-3}$; water $\mathrm{pH}=7.40$; organic matter $=$ $25.20 \mathrm{~g} \mathrm{dm}^{-3} ; \mathrm{P}=149.02 \mathrm{mg} \mathrm{dm}^{-3} ; \mathrm{K}=0.25 \mathrm{cmol}_{\mathrm{c}}$ $\mathrm{dm}^{-3} ; \mathrm{Ca}^{2+}=7.55 \mathrm{cmol}_{\mathrm{c}} \mathrm{dm}^{-3} ; \mathrm{Mg}^{2+}=2.24 \mathrm{mg} \mathrm{dm}^{-}$ ${ }^{3} ; \mathrm{S}=152.48 \mathrm{mg} \mathrm{dm}^{-3} ; \mathrm{Cu}=17.77 \mathrm{mg} \mathrm{dm}^{-3} ; \mathrm{Zn}=$ $33.94 \mathrm{mg} \mathrm{dm}{ }^{-3} ; \mathrm{Mn}=103.70 \mathrm{mg} \mathrm{dm}^{-3} ; \mathrm{Fe}=$ $169.00 \mathrm{mg} \mathrm{dm}^{-3} ; \mathrm{B}=4.10 \mathrm{mg} \mathrm{dm}^{-3}$. As physical composition, the soil presented $122,60 \mathrm{~g} \mathrm{~kg}^{-1}$ of sand, $120,60 \mathrm{~g} \mathrm{~kg}^{-1}$ of silt, 756,80 $\mathrm{g} \mathrm{kg}^{-1}$ of clay and soil bulk density of $1,34 \mathrm{Mg} \mathrm{m}^{-3}$.

Base dressing was made based on the soil analysis and recommendations by Pauletti and Motta (2017). Urea, simple superphosphate, and potassium chloride were used as $\mathrm{N}, \mathrm{P}$, and $\mathrm{K}$ sources, respectively, besides $3 \mathrm{~kg} \mathrm{~m}^{-2}$ of tanned poultry manure. During the seedlings transplant, 15 and 30 days after transplant (DAT) boric acid $\left(1 \mathrm{~g} \mathrm{~L}^{-1}\right.$ ) was applied (foliar spray) as the source of boron. At $15 \mathrm{DAT}$, ammonium molybdate $\left(0.5 \mathrm{~g} \mathrm{~L}^{-}\right.$ $\left.{ }^{1}\right)$ was applied (foliar spray) to provide molybdenum. Top-dressing was made with urea and potassium chloride at 15, 30, 45, and 60 DAT through fertigation.

After soil tillage and fertilizers incorporation, 48 plots were prepared inside the greenhouse, measuring $3 \mathrm{~m}$ long and $0.5 \mathrm{~m}$ wide. Seedlings were transplanted with the spacing of 1 
$\mathrm{m}$ between rows and $0.5 \mathrm{~m}$ between plants. Irrigation was done using a drip irrigation system, where each plot contained 12 self-compensating drippers (flow rate of $4 \mathrm{~L} \mathrm{~h}^{-1}$ ) spaced $0.25 \mathrm{~m}$ between each one. Seedlings were produced in 128-cell expanded polystyrene trays containing commercial substrate and using the 'Barcelona' cauliflower hybrid. When seedlings showed between three and four leaves, they were transplanted.

ETc was determined using three constants water table lysimeters installed inside the greenhouse. Lysimeters were built with polyvinyl chloride (PVC) boxes $(1.05 \mathrm{~m}$ in diameter, $0.65 \mathrm{~m}$ deep, and $380 \mathrm{~L}$ capacity). To install, three circular trenches were opened, separating soil according to the different layers. At the bottom was placed a $0.50 \mathrm{~m}$ crushed stone layer with geotextiles to avoid the obstruction of water intake caused by soil particles. After this procedure, the soil was replaced inside the boxes respecting the same layer order when removed.

Each lysimeter was connected to an intermediate tank, made in a $200 \mathrm{~mm}$ PVC tube with $0.80 \mathrm{~m}$ high and the bottom sealed to prevent leaks. One float valve was installed, allowing water intake in the intermediate tank supplied by another tank (supply tank) used to measure the water volume consumed. Everyday water consumed was read in the supply tank, and the level water was replaced, keeping the water table constant.

Before crop installation, lysimeters were saturated and draining three times to guaranteed particle soil rearrangement. Two cauliflower plants were transplanted to each lysimeter, $0.5 \mathrm{~m}$ spaced. With crop development, evapotranspiration reduces the water table level supplied by the supply tank and changes the supply tank level. Assisted by a graduated ruler installed inside the supply tank, the water consumed was measured.

The read of supply tank level and the level of water replacement was made every day at
8:00 am. Evapotranspiration (ETc) was calculated using the difference between the current day read and last day read. The average of the three lysimeters determined the daily water consumption for the crop. ETo value was obtained by Penman-Monteith equation, according to the FAO recommendation (ALLEN et al., 1998). Climate data used for ETo determination were registered by a weather station (Davis Instruments, Hayward, California, USA) installed $1.2 \mathrm{~m}$ high at the greenhouse center, data was stored in a datalogger. Cauliflower crop coefficient $(\mathrm{Kc})$ was determined considering ETc without water restriction and ETo.

To calculate the mean $\mathrm{Kc}$, the crop cycle was divided into three phenological stages defined by Allen et al. (1998): initial stage: from sowing to when plant presents between 7 and 10 leaves; intermediate stage: from 7-10 leaves to the appearance of inflorescence in the meristem; final stage: from the appearance of the inflorescence to the harvest. However, according to the field observation, the crop cycle was also divided into four phenological stages (ABDELKHALIK et al., 2019). The intermediate stage was divided to do a better demonstration of water consumption during this stage.

This paper does not have treatments for being a deterministic analysis, so it is not necessary a statistical design. Using data collected, ETo, ETc, and Kc's values were determined using spreadsheet software Microsoft Excel .

\section{Results and discussion}

During crop development, there were registered temperatures between $0.4{ }^{\circ} \mathrm{C}$ and 37.8 ${ }^{\circ} \mathrm{C}$, and the mean temperature was $17.9{ }^{\circ} \mathrm{C}$ (Figure 1). Barcelona hybrid is classified as a midseason hybrid (MAY et al., 2007), thus registered temperature was considered good to crop development. 
Figure 1. Relative air humidity, minimum, maximum, and mean temperature inside the greenhouse.

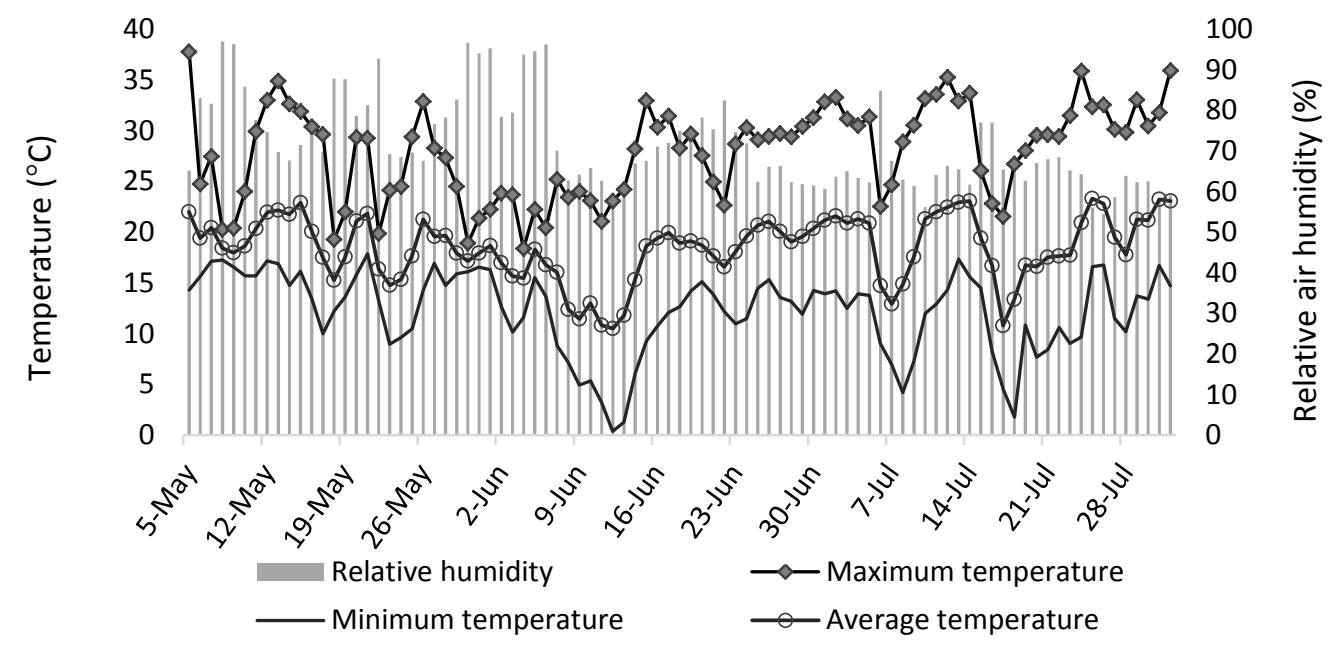

Midseason cultivars can tolerate higher temperatures during the development, therefore, temperature fluctuation is less prejudiced for this cultivar type than winter cultivars. According to MAY et al. (2007), the best temperature for cauliflower development is between $14{ }^{\circ} \mathrm{C}$ and 20 ${ }^{\circ} \mathrm{C}$, above this temperature, physiological disorders can occur, affecting inflorescence quality and hindering commercialization. Temperatures below $14{ }^{\circ} \mathrm{C}$ affect plant growth.

With air temperature increase, molecule energy levels also increase and create a larger difference between vapor pressure and saturation pressure, resulting in evapotranspiration increase. When the relative humidity increase can decrease plant transpiration because the vapor concentration gradient between the stomatal cavity and the adjacent air to the leaf also decrease, caused by the reduction of air vapor saturation deficit (LOZANO et al., 2017; TAIZ; ZEIGER, 2017).

Figure 2 represents the crop evapotranspiration demands during the crop cycle.

Figure 2. Crop evapotranspiration demands during the crop cycle of cauliflower, Maringá - PR.

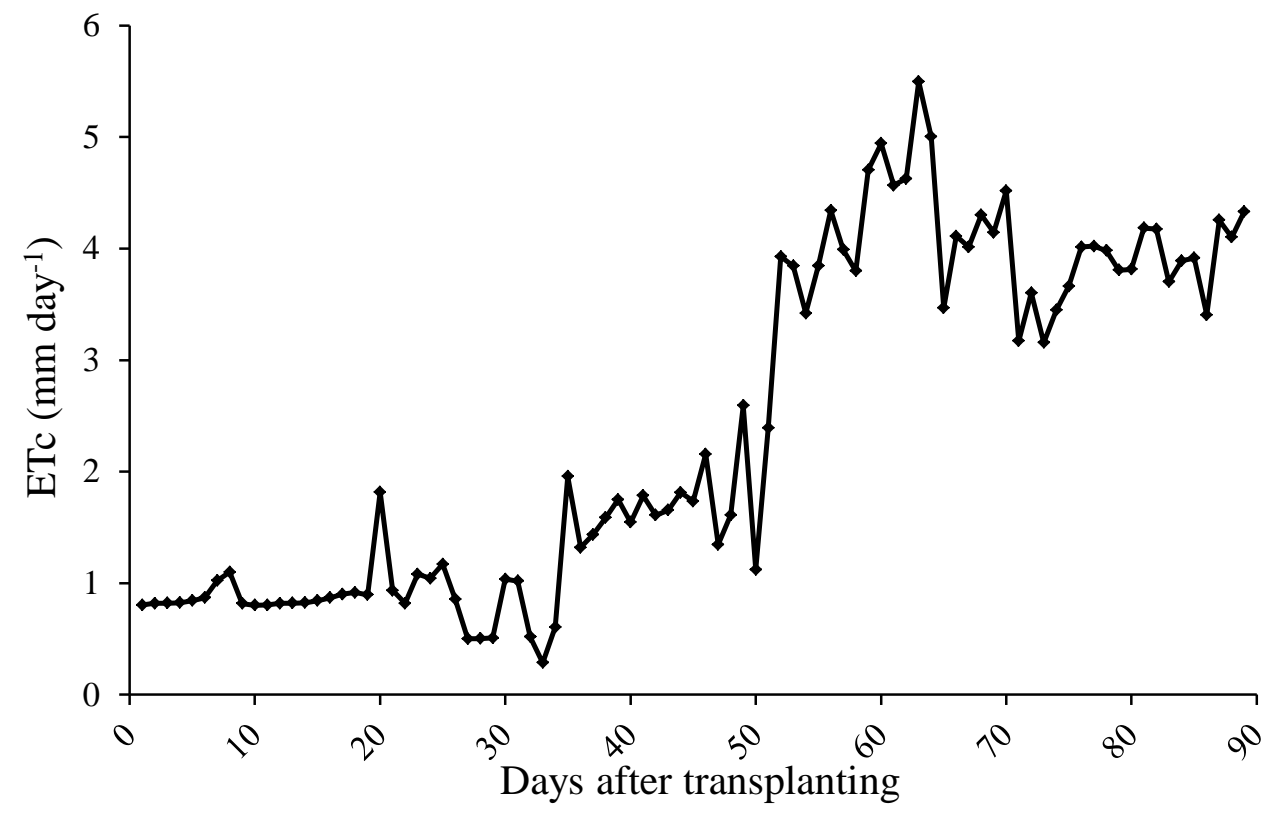


Total water consumption was $215.11 \mathrm{~mm}$ during 92 cycle days after transplant. Mean evapotranspiration was $2.34 \mathrm{~mm} \mathrm{day}^{-1}$. The highest ETc value was observed between 50 DAT and 75 DAT, and $5.49 \mathrm{~mm} \mathrm{day}{ }^{-1}$ was the maximum value. Parekh (2014) evaluated the water consumption for cauliflower cultivated in the open field, obtaining a consumption of 237 $\mathrm{mm}$.

Evapotranspiration demands for stage I (1 - 32 DAT) were $32.44 \mathrm{~mm}$, where the minimum value was $0.41 \mathrm{~mm} \mathrm{dia}^{-1}$ and maximum $1.80 \mathrm{~mm}$ day $^{-1}$. This phase can be understood as plant adaptation time to the ambient conditions. Crop roots will be developed along with the soil profile, demanding more nutrients and increasing the photosynthetic rate for vegetal development. According to Oliveira Gondin et al. (2011), roots represent the main part of vegetative mass increase when related with other cauliflowers parts until 30 DAT.

During stage II (33 - 61 DAT), occurred the increase in the number of leaves considering that the crop establishment has already happened. Water consumption was $61.12 \mathrm{~mm}$, and $4.34 \mathrm{~mm}$ day $^{-1}$ was the maximum consumption that was registered at the end of this stage. From 50 DAT, the water demand followed the leaf expansion (reach an average of 18 developed leaves) and the beginning of flower primordia appearance that presented a mean diameter of $2.1 \mathrm{~cm}$. Barreto et al. (2017) and Sohail et al. (2018) affirm that the leaf area index
(LAI) is related with the uptake of water and nutrients by the plants, the presence of limiting factors can affect this relationship.

Stage III (62 - 74 DAT) was characterized by the inflorescence growth, therefore, needing a larger water consumption. This stage lasted 13 days, and the total ETc was $51.17 \mathrm{~mm}$ (maximum value was $5.49 \mathrm{~mm}$ day $^{-1}$ ). The ETc differs between stage II and stage III was $9.95 \mathrm{~mm}$. Still, stage III presented 16 days less, evidencing that inflorescence development demands more water, which is a critical stage during cauliflower development.

Stage IV (75 - 92 DAT) is the maturation period when the inflorescence growth ends, and the harvest begins. At this stage, the water demands stabilized, the maximum ETc was 4.14 $\mathrm{mm}$ day $^{-1}$. The crop cycle was 48 days less when compared to the cauliflower cycle determined by FAO. According to FAO (ALLEN et al., 1998), the total cycle of cauliflower was 140 days, being 35, 60 , and 45 days for stage I, II, and III, respectively.

Cauliflower Kc values, determined by the division between ETc and ETo, were higher than the reference values presented in the FAO Irrigation and drainage paper 56. According to Allen et al. (1998), under frequent wetting conditions, the Kc values can increase with high irrigation frequency or rain. Table 1 demonstrates the comparison between the Kc obtained and the Kc reported by FAO.

Table 1. Cauliflower crop coefficient $(\mathrm{Kc})$ calculated and tabled Kc by FAO.

\begin{tabular}{ccc}
\hline \multirow{2}{*}{ Phenological stage } & \multicolumn{2}{c}{ Crop coefficient (Kc) } \\
\cline { 2 - 3 } & Calculated & FAO \\
\hline Initial & 0.74 & 0.65 \\
Intermediate & 1.86 & 1.05 \\
Final & 1.50 & 0.95 \\
\hline
\end{tabular}

At all phenological stages, the Kc calculated was larger than Kc reported by FAO. Kc calculated was $0.74,1.86$, and 1.50 higher for the initial, intermediate, and final stages. According to Parekh (2013), the leaf area is small during the initial period, and the evapotranspiration is compound basically for water evaporation from the soil. The Kc can also increase when the soil is frequently wetted during the initial stage, this way, the Kc value can be higher due to soil conditions, which provide larger water evaporation. Parameters as a cultivar life cycle, planting location, and season also can influence the $\mathrm{Kc}$ calculated. The season and planting location influence the environmental conditions that will influence the crop life cycle; in this case, the life cycle was reduced, contributing to 
increase the daily ETc and consequently increase the $\mathrm{Kc}$.

It is possible to notice that Kc reported by FAO underestimates the value obtained experimentally. Using the Kc reported by FAO, the water volume applied during the irrigation will be smaller than real plant necessity, restricting water availability for the crop and causing production losses. The determination of the FAO kc is carried out in desert conditions in the United States, that is, in conditions totally different from those of the Brazilian regions (ALLEN et al., 1998).

Thus, the values found locally for the plants shows the need for specific research on water consumption and the crop coefficient at the site and with the cultivar to be implanted. According to Yanglem and Tumbare (2014), when cauliflower is submitted to hydric stress, the evapotranspiration decrease happens caused by the stomatal conductance reduction. It will influence photosynthesis rates, consequently, the plant growth too. Under adequate soil humidity conditions, the plant can keep the photosynthesis rates, favoring the inflorescence growth, improving yield.

Lazzara and Rana (2010) reported that FAO reports underestimated the $\mathrm{Kc}$ for different crops such as cauliflower, red cabbage, lettuce, and melon. Therefore, it is essential to develop regional research, specifying the Kc values for different crops in all their phenological stages, considering that most references $\mathrm{Kc}$ were determined in the Mediterranean region. Besides, only $10 \%$ of main food-producing countries have a regionalized $\mathrm{Kc}$ value.

For López-Urrea et al. (2009), it is essential that there are local experiments for the determination of $\mathrm{Kc}$, making the estimation of ETc more precise and, consequently, improving irrigation management. The author also points out that the equations' incapacity causes the differences between ETc values measured through lysimeters and the values calculated from the formulas provided by FAO irrigation and drainage paper 56 to capture the effect of all climate parameters combinations.

Although the higher Kc values obtained in the present study indicate a higher demand for irrigation water, yield also increases. Water use efficiency (WUE) is the variable that determines the efficiency of water management, which is if the water is being used well. When water is applied in quantity demanded by the crop, the yield tends to be maximum (if the other factors are adequately supplied), thus, the water use efficiency (LÓPEZ-URREA et al., 2009). Wrongly estimating the $\mathrm{Kc}$, it can overestimate the value and increase the use of water, decreasing production efficiency and change post-harvest aspects of the product (HACHMANN et al., 2019; SHAMS; FARAG, 2019; WENNECK et al., 2021).

The Kc values provided by FAO are useful as a reference in the absence of local data. Irrigation should be based on Kc values provided by FAO than to be carried out without criteria; however, whenever possible, local Kc values should be used, or at least values obtained for situations closer to cultivation condition.

\section{Conclusions}

According to the present study, the Kc values of cauliflower cultivated in a greenhouse under a humid subtropical climate are $0.74,1.86$, and 1.50 for the initial, intermediate and final stages, respectively. The water consumption was $32.44,112.29$, and $70.38 \mathrm{~mm}$ for the three stages, respectively, totalizing a water consumption of $215.11 \mathrm{~mm}$.

Thus, it was possible to observe that the reference values of FAO irrigation and drainage paper 56 underestimate the values found locally for the Barcelona hybrid. This shows the need for specific research on water consumption and the crop coefficient at the site and with the cultivar to be implanted.

\section{References}

ABDELKHALIK, A.; PASCUAL, B.; NÁJERA, I.; BAIXAULI, C.; PASCUAL-SEVA, N. Deficit irrigation as a sustainable practice in improving irrigation water use efficiency in cauliflower under Mediterranean conditions. Agronomy, v. 9, n. 11, p.732, 2019. https://doi.org/10.3390/agronomy9110732

ALLEN, R. G.; PEREIRA, L. S.; RAES, D.; SMITH, M. Crop evapotranspiration: guidelines for computing crop water requirements. Rome: FAO Irrigation and Drainage Paper, 1998. 56p.

BARBOSA, B. D. S.; OLIVEIRA, F. G.; FIGUEIREDO, F. P. Determinação do coeficiente de cultivo $(\mathrm{Kc})$ do Capim Tanzânia irrigado no norte de Minas Gerais. Irriga, v. 1, n. 2, p. 11-20, 2015. https://doi.org/10.15809/irriga.2015v1n2p11 
BARRETO, R. F.; SCHIAVON JÚNIOR, A. A.; MAGGIO, M. A.; PRADO, R. D. Silicon alleviates ammonium toxicity in cauliflower and in broccoli. Scientia Horticulturae, v. 225, n. 1, p. 743-750, 2017.

https://doi.org/10.1016/j.scienta.2017.08.014

COUTINHO, E. R.; MADEIRA, J. G. F.; SILVA, R. M.; OLIVEIRA, E. M.; DELGADO, A. R. S. Avaliação de Métodos de Estimativa da Evapotranspiração de Referência (ETo) Diária Para Regiões dos Estados do Rio de Janeiro e Espírito Santo. Revista Brasileira de Meteorologia, v. 35, n. 4, p. 649655, 2020. https://doi.org/10.1590/0102$\underline{77863540069}$

FERREIRA, A. R.; JÚNIOR, J. A. L.; OLIVEIRA, P. D.; AVIZ, W. L. C.; SANTOS, H. C. A. Desempenho produtivo de Couve-flor submetida a diferentes manejos de irrigação e doses de boro em ambiente protegido. Revista Engenharia na Agricultura, v. 27, n. 5, p. 440-451, 2019. https://doi.org/10.13083/reveng.v27i5.915

HACHMANN, T. L.; REZENDE, R.; PINTRO, P. T. M.; SAATH, R.; ANJO, F. A.; MENEZES, C. S. L. Yield, antioxidant activity and shelf-life of cauliflower inflorescences under drought stress and foliar spraying of selenium. Ciência e Agrotecnologia, v.43, e017819, 2019. https://doi.org/10.1590/1413-

$\underline{7054201943017819}$

LAZZARA, P.; RANA, G. The use of crop coefficient approach to estimate actual evapotranspiration: a critical review for major crops under Mediterranean climate. Italian Journal of Agrometeorology, v. 15, n. 2, p. 25-39, 2010.

LÓPEZ-URREA, R.; MONTORO, A.; LÓPEZ-FUSTER, P.; FERERES, E. Evapotranspiration and responses to irrigation of broccoli. Agricultural Water Management, v. 96, n. 7, p. 1155-1161, 2009. https://doi.org/10.1016/j.agwat.2009.03.011

LOZANO, C. S.; REZENDE, R.; FREITAS, P. S. L.; HACHMANN, T. L.; SANTOS, F. A. S.; ANDREAN, A. F. B. A. Estimatation of evapotranspiration and crop coefficient of melon cultivated in protected environment. Revista Brasileira de Engenharia Agrícola e Ambiental, v. 21, n. 11, p. 758-762, 2017. DOI: http://dx.doi.org/10.1590/18071929/agriambi.v21n11p758-762
MANGAROTTI, D. P. O.; REZENDE, R.; SAATH, R.; HACHMANN, T. L.; LOZANO, C. S.; GONÇALVES, A. C. A. Water requirements and crop coefficients of arugula grown in a protected environment. Idesia, v.37, n.2, p.75-79, 2019. http://dx.doi.org/10.4067/S0718$\underline{34292019000200075}$

MAY, A.; TIVELLI, S. W.; VARGAS, P. F.; SAMRA, A. G.; SACCONI, L. V.; PINHEIRO, M. Q. A Cultura da Couve-Flor. Campinas: Instituto Agronômico, 2007. (Boletim Técnico IAC)

MONTANHER, O. C.; MINAKI, C. Precipitação em Maringá-PR: estatísticas descritivas, tendência de longo prazo e probabilidade de eventos extremos diários. Revista do Departamento de Geografia, v.39, p.138-153, 2020. https://doi.org/10.11606/rdg.v39i0.164209

OLIVEIRA GONDIN, A. R.; PRADO, R. M.; CORREIA, M. A. R.; ALVES, A. U.; FILHO, A. B. C.; POLITI, L. S. Curva de crescimento e acúmulo de matéria seca em couve-flor cultivada em substrato. Bioscience Journal, v. 27, n. 1, p. 88-94, 2011.

OLIVEIRA, F.A.; SANTOS, C. A.; COSTA, E, S. P.; GOULART, R. G. T.; ANDRADE, N. F.; DINIZ, G. S.; CARMO, M. G. F. Desempenho de híbridos de couve-flor nas condições da baixada fluminenseRJ. Revista Brasileira de Agropecuária Sustentável, v. 8, n. 1, p. 30-36, 2018. https://doi.org/10.21206/rbas.v8i1.470

PAREKH, F. Crop water requirement using single and dual crop coefficient approach. International Journal of Innovative Science Engineering and Technology, v. 2, n.9, p. 4493-4499, 2013.

PAULETTI, V.; MOTTA, A. C. V. Manual de adubação e calagem para o estado do Paraná. Curitiba: SBCS-NEPAR, 2017.

PEREIRA, M. E. M.; JUNIOR, J. A. L.; LIMA, V. M.; GUSMÃO, S. A. L.; OLIVEIRA, P. D.; SILVA, A. L. P. Viabilidade econômica da produção de couve-flor irrigada por gotejamento no Nordeste Paraense. Amazonian Journal of Agricultural and Environmental Sciences, v. 61, p.1-8, 2018. https://doi.org/10.22491/rca.2018.2738

SANTOS, F. A. S.; MENEZES, C. S. L.; REZENDE, R.; FREITAS, P. S. L.; SOUZA, A. H. C.; TERASSI, D. S. 
Irrigation management based on evapotranspiration accumulation of the melon crop: a Bayesian approach. Revista Brasileira de Ciências Agrárias, v.15, n.2, e7181, 2020. https://doi.org/10.5039/agraria.v15i2a7181

SANTOS, G. O.; VANZELA, L. S.; FARIA, R. T. Manejo da Água na Agricultura Irrigada. Associação Brasileira de Engenharia Agrícola, 2018. 40p. (Boletim Técnico)

SANTOS, H. G.; JACOMINE, P. K. T.; ANJOS, L. H. C.; OLIVEIRA, V. Á.; LUMBRERAS, J. F.; COELHO, M. R.; ALMEIDA, J. A.; ARAÚJO FILHO, J. C.; OLIVEIRA, J. B.; CUNHA, T. J. F. Sistema brasileiro de classificação de solos. 5. ed. EMBRAPA, 2018. $353 p$.

SHAMS, A. S.; FARAG, A. A. Implications of water stress and organic fertilization on growth, yield and water productivity of cauliflower (Brassica oleracea var. botrytisL.). Journal of Plant Production, v. 10, n. 10, p. 807-813, 2019. https://doi.org/10.21608/ipp.2019.59471

SOHAIL, N. K.; ULLAH, Z.; AHMAD, J.; KHAN, A.; NAWAZ, F.; KHAN, R. Effect of deficit irrigation and nitrogen levels on growth and yield of cauliflower under drip irrigation. Pure and Applied Biology, v. 7, n. 2, p. 910-921, 2018. http://dx.doi.org/10.19045/bspab.2018.700112

TAIZ, L.; ZEIGER, E. Fisiologia vegetal. 5. ed. Porto Alegre: Artmed, 2017.

WENNECK, G. S.; SAATH, R.; REZENDE, R.; ANDREAN, A. F. B. A.; SANTI, D. C. Resposta agronômica de couve-flor à adição de silício ao solo sob estresse hídrico. Pesquisa Agropecuária Tropical, Goiânia, v.51, e66908, 2021. https://doi.org/10.1590/1983-

40632021v5166908

YANGLEM, S. D.; TUMBARE A. D. Influence of irrigation regimes and fertigation levels on yield and physiological parameters in cauliflower. The Bioscan, v. 9, n. 2, p. 589-594, 2014. 